\title{
¿Plástico o pseudoplástico?. Métodos de determinación y análisis del punto de fluidez de suspensiones cerámicas
}

\author{
C. GUTIÉRREZ*, A. JAVIER SÁNCHEZ-HERENCIA, R. MORENO \\ Instituto de Cerámica y Vidrio, CSIC. 28500 Arganda del Rey, Madrid
}

\begin{abstract}
En los últimos años se ha popularizado el empleo de técnicas reométricas tales como la medida en esfuerzo controlado o los ensayos de oscilación. En este trabajo se revisan los conceptos básicos de reología de suspensiones y se analizan las técnicas reométricas más recientes para su completa caracterización. A partir de una suspensión previamente optimizada de porcelana sanitaria, con un contenido en sólidos de $50 \%$ en volumen, se describen y analizan distintos tipos de ensayos reológicos, los modelos de regresión más frecuentes y sus limitaciones y las posibles formas de representar los datos de un reograma para conseguir una máxima información. Se discuten las posibles diferencias entre los parámetros reológicos obtenidos mediante distintas determinaciones reométricas, centrando el interés en la determinación de los puntos de fluidez, clave para distinguir un comportamiento plástico de uno pseudoplástico.
\end{abstract}

\section{Plastic o pseudoplastic?. Methods for determining and analising the yield stress of ceramic slips}

In the last years the use of rheometric techniques like control stress and oscillation measurements has become popular. In this work the basic concepts of suspensions rheology are revised and the recent rheometric techniques for their complete characterisation are analysed. From a previously optimised slip of sanitary porcelain with a solid loading of $50 \mathrm{vol} \%$, different kinds of rheological tests and the most frequent regression models are described and analysed, as well as the limitations and the possible ways to plot a rheogram in order to reach a maximum information. The differences among rheological parameters obtained in different ways are discussed, focusing the determination of the yield stress which is the key to distinguish a plastic behaviour from a pseudoplastic one.

Key words: Suspensions, rheology, rheometry, sanitary porcelain, plasticity, yield stress

\section{INTRODUCCIÓN}

La industria cerámica emplea frecuentemente suspensiones, barbotinas y pastas, cuyas propiedades reológicas afectan a las distintas etapas del proceso, desde el diseño y selección de equipos de bombeo, transporte y almacenamiento, al mezclado y molienda de los distintos componentes de la formulación y, por supuesto, a las operaciones de conformado, sea a partir de suspensiones, como las técnicas de colaje con o sin presión, a partir de pastas, como en las técnicas de moldeo y extrusión, e incluso en las técnicas de prensado en seco, en donde el polvo debe ser atomizado para optimizar el empaquetamiento, lo cual requiere también una suspensión estable y homogénea. En cerámica blanca y sanitarios, además, las suspensiones son clave en la aplicación de engobes y esmaltes.

Por ello, el estudio de la reología de suspensiones ha ocupado un lugar destacado tanto en la investigación y desarrollo de materiales cerámicos, como en el control de calidad de los productos industriales (1-4).

Las barbotinas y pastas empleadas en la industria cerámica son sistemas de elevada complejidad, dados el número y variedad de sus componentes. Esto dificulta la caracterización

\section{INTRODUCTION}

Ceramics industry frequently uses suspensions, slips or pastes, whose rheological properties influence the different processing steps from design and selection of pumping equipments, transport and storage, mixing and milling of the several components of the formulation and the subsequent forming operations, either when starting from suspensions -such as slip or pressure casting-, pastes -as in extrusion or injection methods- and even in dry pressing where powders are previously atomised to improve packing thus requerring a stable and homogeneous slip. In addition, slips are essential in the field of whitewares and sanitarywares when forming enamels and engobes.

For this reason, the study of slip rheology has a relevant position either in the research and development of ceramic materials or in the quality control of industrial products (1-4).

Industrial slips and pastes are extremely complex systems due to the number and variety of their components. This difficults the characterisation and modelling of their behaviour. The rheology of such slips and pastes depends on 
y modelización de su comportamiento. La reología de suspensiones y pastas depende de muchos factores como son, entre otros, el contenido en sólidos y la forma y distribución de tamaños de las partículas suspendidas, ya que éstas pueden cubrir un rango de tamaños muy amplio, desde gránulos de varias decenas de micrómetros a partículas coloidales $(<1 \mu \mathrm{m})$, y formas muy diversas, desde redondeadas a fibras o plaquetas.

Las partículas inmersas en un medio líquido interaccionan entre sí y con las moléculas del propio líquido. La energía de interacción depende de los parámetros anteriores y de la propia naturaleza de los polvos, que determina las características de la doble capa eléctrica que se desarrolla en torno a las partículas dispersas. En suspensiones concentradas, los contactos entre partículas son frecuentes, dada su proximidad, por lo que se hace necesario el uso de defloculantes para favorecer la repulsión entre ellas y, por tanto, asegurar la estabilidad de la suspensión y la homogeneidad microestructural en la pieza conformada. El método más extendido para seleccionar las condiciones óptimas de dispersión de una suspensión o pasta es el estudio de las curvas de defloculación, en las que se determina la concentración requerida de defloculante para proporcionar a la mezcla una mínima viscosidad.

Las crecientes exigencias impuestas por un mercado cada vez más competitivo han fomentado el empleo de técnicas instrumentales más precisas que permitan un control riguroso de las etapas del proceso de fabricación (5-7). La caracterización reológica no ha quedado al margen de esta evolución, sino que ha suscitado un creciente interés en el ámbito industrial. Así, en la actualidad, es habitual, tanto en la investigación como en la industria, el control de los parámetros reológicos de las suspensiones utilizando técnicas que introducen un cierto grado de sofisticación, como es el empleo de viscosímetros rotacionales $(8,9)$. En ellos, la posibilidad de determinar curvas de flujo en las que se miden centenares de puntos, que se recogen y analizan mediante un ordenador, han desplazado técnicas reológicas tan establecidas en la industria como los viscosímetros capilares, el método de torsión de Gallenkamp (2), la copa Ford (1), o el viscosímetro rotacional Brookfield. Estos instrumentos eran válidos para sistemas simples, como los newtonianos y, en el mejor de los casos, permitían obtener curvas de flujo a partir de medidas puntuales de viscosidad aparente a distintas velocidades de rotación (método Brookfield), aunque su simplicidad favorecía el uso como sistema de control.

Posteriormente, se extendió el uso de los viscosímetros rotacionales, los cuales permiten obtener curvas de flujo de forma rápida y reproducible con ayuda de un soporte informático. La mayor ventaja de estos viscosímetros es que se mide directamente la viscosidad real de la suspensión. Además, se puede evaluar el comportamiento reológico en un amplio rango de gradientes de velocidad, así como los efectos dependientes del tiempo (tixotropía).

El avance más reciente de la reometría se refiere a la gran difusión experimentada en la última década por los reómetros de esfuerzo controlado y oscilación. Estos reómetros introducen un grado de sofisticación importante, por lo que su uso y la interpretación de los resultados, requiere un adiestramiento específico. De esta forma, se ha extendido el uso de las medidas en modo de esfuerzo controlado (CS), así como los parámetros que definen la viscoelasticidad de suspensiones y pastas, mediante medidas de esfuerzo/deformación y mediante los ensayos de oscilación (9-11). La información que se recaba con un adecuado estudio reométrico en estos modos de operación permite conocer el comportamiento de las suspensiones many factors including the solid content and the shape and size distribution of the suspended particles, since they can cover a broad range from granules of several decades of micrometers down to colloidal sizes $(<1 \mu \mathrm{m})$ and different shapes, from spherical to platelet-like.

The particles immersed in a polar liquid interact among them and with the liquid molecules. The interaction energy depends on the above parameters and on the nature of the powders that determines the characteristics of the electrical double layer developed around the particles surface. In concentrated suspensions contacts among particles are frequent thus making necessary the use of deflocculants to allow the proper repulsion and to assure the stability of the suspension and the microstructural homogeneity in the final shaped body. The most usual method for determining the optimal dispersing conditions of a slip or paste is by means of deflocculation curves in which the concentration of deflocculant required to provide a minimum viscosity is obtained.

The growing necessities of a more and more competitive market have promoted the employment of more precise instrumental techniques that provide an accurate control of the fabrication steps (5-7). Rheological characterisation is not an exception and has suscited an increasing interest in the industry. Nowadays it is usual the control of rheological parameters using sophisticated techniques not only in the reseach but also in the industry, as in the case of rotational viscosimeters $(8,9)$. In these the possibility of determining flow curves by measuring hundreds of points which are collected and analysed by a computer have substituted rheological techniques as capillary viscosimeters, the Gallenkamp torsion method (2), the Ford cup (1) or the Brookfield rotational viscosimeter, very frequently used in the industrial sector. These instruments were valid for simple systems, as the Newtonian, and allowed only to obtain flow curves from punctual measurements of apparent viscosity at different shear rates (Brookfield method) although their simplicity was adequate for controlling purposes.

Afterwards the use of rotational viscosimeters increased since they allowed to obtain flow curves in a rapid and reliable way with the help of computers. The biggest advantage of theses viscosimeters is that they measure the "real" viscosity of the suspension. Fuerthermore, it is possible to evaluate the rheological behaviour in a broad range of shear rates as well as the time dependency effects (thixotropy).

The most recent advance in rheometry refers to the big diffusion of control stress and oscillation rheometers. These introduce an important sophistication degree and thus, their use and the interpretation of the results need a specific training. The use of control stress (CS) measurements and the parameters defining the viscoelastic properties by either creep/recovery tests or forced oscillation have become popular (9-11). The information provided with an adequate rheometric study in those operation modes allow to know the behaviour in a broader range of shear stress or rate as well as in stationary conditions, as in the case of storage or pouring a slip for casting into the mould. All this information allows also to correlate the rheology with the interaction potentials developed among particles so that the design and preparation of suspensions are better controlled (12-15).

The aim of this work is to review the basic concepts involved in the rheology of concentrated slips and to present the possibilities of applicating modern rheometric techniques in ceramic industry, facilitating some criteria to detemine the yield stress and other rheological parameters. For this pur- 
en rangos de esfuerzo y velocidad mucho más amplios, así como en condiciones estacionarias, como son el almacenamiento en un recipiente en reposo, o la suspensión vertida en un molde durante el colaje. Toda esta información permite, además, correlacionar la reología con los potenciales de interacción que se desarrollan entre las partículas, lo que permite ejercer un mejor control en el diseño y preparación de suspensiones (12-15).

El objetivo del presente trabajo es revisar los conceptos básicos de la reología de suspensiones concentradas y dar a conocer las posibilidades de aplicación de las técnicas reométricas modernas en la industria cerámica, facilitando algunos criterios para la determinación del punto de fluidez y otros parámetros reológicos. Para ello se ha utilizado una suspensión de formulación prefijada. El comportamiento reológico ha sido previamente estudiado en función de distintos tipos y concentraciones de defloculantes, pero no se analizan en este trabajo.

\section{EXPERIMENTAL}

Para ilustrar los conceptos básicos de reometría y evaluar la información que se puede obtener con las medidas, se ha utilizado una suspensión de porcelana sanitaria con un contenido en sólidos del $50 \%$ vol (72,5\% peso) defloculada con un $0,4 \%$ peso de un polielectrolito comercial de bajo contenido en sodio (Dolapix PCN, Zschimmer-Schwarz, Alemania).Un estudio previo utilizando distintos tipos y concentraciones de defloculantes (silicato sódico, carbonato sódico, y distintas mezclas de ellos) reveló que el aditivo empleado proporciona viscosidades inferiores y, por tanto, mejores condiciones de estabilidad. La suspensión preparada posee una composición típica en la fabricación industrial de sanitarios, con un contenido total de arcillas de $26 \%$, 30\% de caolín, $22 \%$ de feldespato y $22 \%$ de cuarzo. La densidad de la mezcla de polvos es de $2,63 \mathrm{~g} / \mathrm{cm}^{3}$. $\mathrm{El}$ análisis semicuantitativo por DRX revela la presencia de caolinita, cuarzo, minerales micáceos (illita), albita y ortoclasa, así como otros componentes minoritarios.

Las suspensiones se han preparado añadiendo el polvo sobre el agua con el defloculante y mezclando enérgicamente con un mezclador de alta cizalla (Silverson L2R, UK) durante 3 min. Tras la cizalla, las suspensiones se han mantenido en agitación durante $1 \mathrm{~h}$ con un agitador de paletas a $450 \mathrm{rpm}$.

La caracterización reológica se ha llevado a cabo usando un reómetro Haake RS50 (Alemania) a temperatura constante de $25^{\circ} \mathrm{C}$. Dicho equipo permite trabajar en el modo de operación clásico de velocidad controlada (control rate, CR), así como en el modo de esfuerzo controlado (control stress, CS). Asimismo, se han llevado a cabo medidas dinámicas para la definición y evaluación de los parámetros viscoelásticos. Las medidas se han efectuado utilizando una geometría de doble cono/placa, con un diámetro de $60 \mathrm{~mm}$ y un ángulo de cono de $2^{\circ}$. Este sistema requiere un volumen de llenado de $\approx 5 \mathrm{ml}$. Cada una de las medidas se ha realizado con una suspensión fresca así preparada, con el fín de que la historia de cizalla fuera la misma en todos los casos.

\section{CURVAS DE FLUJO Y VISCOSIDAD}

En muchos laboratorios la caracterización reológica de suspensiones se ha centrado en la medida de las curvas de flujo (en modo CR), en las que se representa el esfuerzo o tensión de cizalla $(\tau)$ que experimenta la suspensión al ir variando el gradiente de velocidad o velocidad de cizalla $(\dot{\gamma})$. pose a previously optimised formulation has been used, although such previous experiments are not referred in this work.

\section{EXPERIMENTAL}

To illustrate the basic concepts of rheometry and to evaluate the information that can be obtained from rheological measurements a sanitary porcelain slip with a solid loading of $50 \mathrm{vol} \%$ (72.5 wt $\%)$ dispersed with $0.4 \mathrm{wt} \%$ of a commercial polyelectrolyte with low sodium content (Dolapix PCN, Zschimmer-Schwarz, Germany) has been used. Previous studies were performed with different types and concentrations of deflocculant (sodium silicate, sodium carbonate and mixtures of both at different ratio) showing that the selected dispersant provides lower viscosities and hence better stability conditions. The prepared slip has a typical composition for manufacturing sanitaryware, with a total content of clays of $26 \mathrm{wt} \%, 30 \mathrm{wt} \%$ of kaolin, $22 \mathrm{wt} \%$ feldspar and $22 \%$ quartz. The density of the mixture is $2.63 \mathrm{~g} / \mathrm{cm}^{3}$. The XRD semiquantitative analysis reveals the presence of kaolinite, quartz, micaceous minerals (illite), albite and orthoclasa, as well as some minor components.

Slips were prepared adding the powder into deionized water containing the dispersant and energetical mixing with a high shear mixer (Silverson L2R, UK) for 3 min. After shearing the slips were maintained under agitation for $1 \mathrm{~h}$ with helica at $450 \mathrm{rpm}$.

Rheological characterization was performed using a rheometer Haake RS50 (Germany) at a constant temperature of $25^{\circ} \mathrm{C}$. This apparatus allows to measure in the traditional control rate mode (CR), as well as in control stress mode (CS). Furthermore, dynamic measurements have been also performed in order to define and evaluate the viscoelastic parameters. Measurements were performed using a double cone and plate geometry with a diameter of $60 \mathrm{~mm}$ and a cone angle of $2^{\circ}$. This system employes a filling volume of about $5 \mathrm{ml}$. Each measurement was performed with a fresh slip in order to maintain the same shear history in all cases.

\section{FLOW CURVES AND VISCOSITY CURVES}

In many laboratories the rheological characterization of suspensions has focused the determination of flow curves (in CR mode) that measures the shear stress $(\tau)$ imposed to the suspension when the velocity gradient or shear rate $(\dot{\gamma})$ changes. The ratio between both parameters defines the viscosity $(\eta)$. The plot of viscosity as a function of shear rate is known as viscosity curve (8). The simplest behaviour is the Newtonian whose flow curve is represented by a line passing through the origin, that is, the viscosity is the same for any shear rate. In concentrated slips the large quantity of particles promotes the mutual interaction, which gives place to more complex non-Newtonian rheological behaviour. The simplest case of a non-Newtonian fluid corresponds to a straight line that does not pass through the origin, which is known as Bingham plastic flow. This model introduces the concept of yield value as the point where the slip starts to flow. Generally speaking, plasticity would be a curve with a yield value where viscosity decreases when shear rate increases. A similar curve but passing through the origin (without yield point) defines pseudoplasticity. It is not 
La relación entre ambos parámetros define la viscosidad ( $\eta$ ). La representación gráfica de la viscosidad en función del gradiente de velocidad se conoce como curva de viscosidad (8). El comportamiento más sencillo es el newtoniano, que está representado, en la curva de flujo, por una línea recta que pasa por el origen, es decir, la viscosidad es la misma a cualquier gradiente de velocidad. En suspensiones concentradas, la elevada cantidad de partículas favorece su mutua interacción, lo que se traduce en un comportamiento reológico más complejo, no newtoniano. El modelo matemático más simple sería el de una línea recta que no pasa por el origen y corresponde a un flujo plástico de Bingham. Este modelo introduce el punto de fluidez, que debe ser superado para que la suspensión empiece a fluir. La plasticidad, de forma genérica, sería una curva con punto de fluidez en el que la viscosidad disminuye al aumentar el gradiente de velocidad. Una curva similar, pero que pasa por el origen (sin punto de fluidez) define el comportamiento pseudoplástico. A menudo no es fácil distinguir uno de otro, ya que haciendo uso de un viscosímetro $C R$ no se puede determinar un número de valores suficiente a baja velocidad para determinar el punto de corte de la curva con el eje y. El caso contrario, aumento de la viscosidad con el gradiente de velocidad, da lugar a la dilatancia, escasamente tratado en los textos de reología, pero de cierta relevancia en suspensiones concentradas de arcillas y otras partículas con un importante factor de forma, en los que al aumentar la cizalla se favorece el empaquetamiento en estructuras tipo castillo de naipes, mediante interacciones cara-borde (16-17).

Los módelos de ajuste más comunes y las ecuaciones que los describen, se resumen en la Tabla 1. Por una parte, hay modelos lineales en los que el esfuerzo es función lineal del gradiente de velocidad, y modelos no-lineales, en los que la función no es directa, sino que varían de forma potencial. En los modelos no lineales, la ecuación es más compleja, y la curvatura de la curva depende de si el factor de desviación de la linealidad (n) es $\mathrm{n}>1$ (dilatante) o $\mathrm{n}<1$ (pseudoplástica).

Al describir el comportamiento reológico de una suspensión, se suelen ajustar las curvas al modelo que proporciona una mejor regresión. En la práctica, es frecuente llevar a cabo el ajuste de toda la curva de flujo en un amplio rango de gradientes de velocidad. Sin embargo, un ajuste de toda la curva puede no ser acertado, ya que las suspensiones son sistemas complejos, con partículas polidispersas entre las cuales se desarrollan diversos tipos de interacción. El cambio de las condiciones de contorno (esfuerzos o velocidades) cambian la disposición de las partículas y sus energías de interacción y, por tanto, el comportamiento reológico. Así, es frecuente encontrar en suspensiones cerámicas curvas de flujo irregulares, constituidas por distintos tramos, cada uno de los cuales corresponde a un tipo de comportamiento. Esto hace necesario un criterio para el ajuste, ya que un ajuste erróneo puede inducir a errores importantes. Esto se ilustra en la Figura 1.a, que muestra la curva de flujo determinada para la suspensión descrita en la parte experimental, medida en modo CR. Este modo es el habitual de medida, en el que se determina la resistencia que opone la suspensión a fluir (esfuerzo) al imponer un gradiente de velocidad creciente. En dicha representación se muestra una escala normal comprendida entre 0 y unos $600 \mathrm{~s}^{-1}$. La suspensión muestra un comportamiento complejo, en el que se combina un flujo newtoniano a bajas velocidades (0-200 $\mathrm{s}^{-1}$ ) y una aparente dilatancia en la región de elevada velocidad (200-600 s-1). Este cambio de comportamiento reológico deberá ser tenido en cuenta en función del procesamiento, ya que un mezclado muy energético o el transporte a traves de toberas, $\mathrm{o}$
Tabla 1. Modelos Reológicos más COMUNes para el aJUSTE De SUSPENSIONES.

Table 1. Typical Rheological Models used to fit the suspensions BEHAVIOUR.

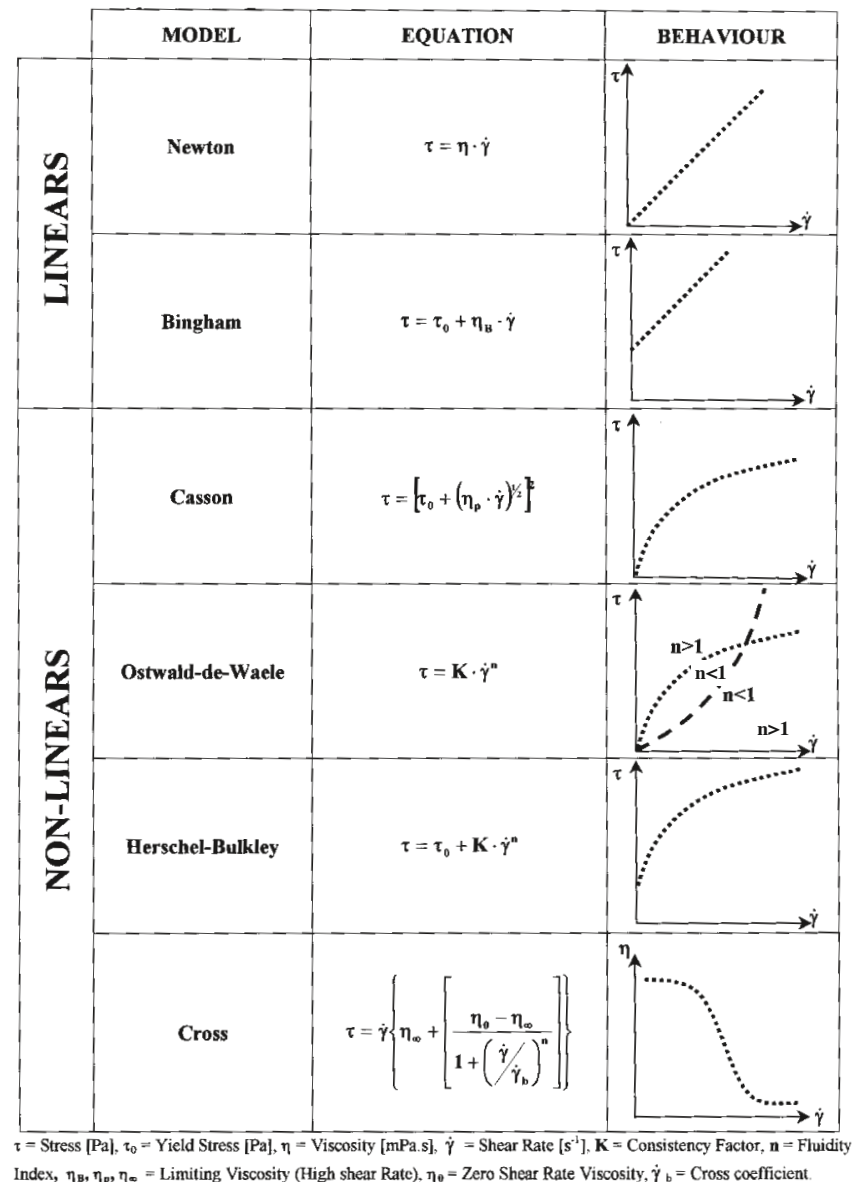

Index, $\eta_{\mathrm{B}}, \eta_{p}, \eta_{\infty}=$ Limiting Viscosity (High shear Ratc), $\eta_{0}=$ Zero Shear Rate Viscosity, $\dot{\gamma}_{b}=$ Cross coefficient.

always easy to distinguish between both because a rotational CR viscosimeter does not provide the required number of values in the low shear region so that the interception with the y axis cannot be determined. The opposite behaviour, when viscosity increases with shear rate, is referred to as dilatancy, which has received less attention in the literature but has important effects in concentrated slips of clays and other particles with a significant shape factor. In such cases an increase of shear stress produces face-to-edge interactions thus promoting the formation of card-house aggregates $(16,17)$.

The most common fitting models and the equations describing them are summarized in Table 1. On one hand there are linear models in which the stress is a linear function of the shear rate and, on the other hand, there are non-linear models where the function is not direct but a power law. In the non-linear models the equation is more complex and the curvature depends on the fact that the deviation from linearity factor $(n)$ is $n>1$ (dilatancy) or $n<1$ (pseudoplasticity).

The rheological behaviour of a suspension is usually adjusted with the model that provides a better regression. In practice, it is usual to fit the whole curve in all the shear rates range. However, this can lead to errors since suspensions are complex systems with polydisperse particles that develope 

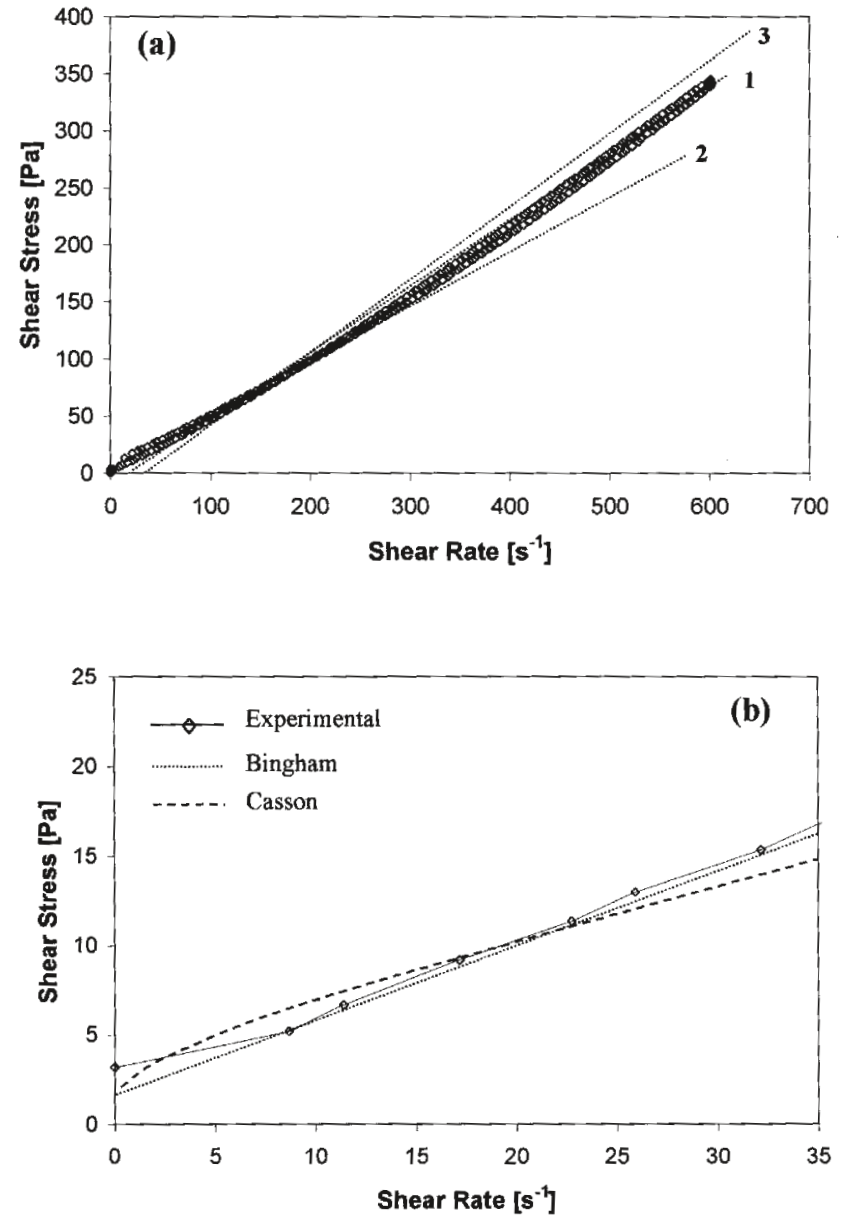

Figura 1. Curva de flujo determinada en modo CR para la suspensión de porcelana sanitaria al $50 \%$ en volumen; a) Ajuste del modelo de Bingham considerando diferentes rangos de medición (1, 0-600 $\mathrm{s}^{-1}$; $\left.2,0-200 \mathrm{~s}^{-1} ; 3,200-600 \mathrm{~s}^{-1}\right)$, b) Detalle en el rango $0-35 \mathrm{~s}^{-1}$, ajuste de Bingham y Casson.

Figure 1. Flow curve obtained in CR mode of a $50 \mathrm{vol} \%$ sanitary porcelain, a) regression to Bingham model at different shear rate ranges $\left.\left(1,0-600 \mathrm{~s}^{-1} ; 2,0-200 \mathrm{~s}^{-1} ; 3,200-600 \mathrm{~s}^{-1}\right), \mathrm{b}\right)$ Detail in the range $0-35 \mathrm{~s}^{-1}$, for Bingham and Casson fittings.

la inyección a alta presión provocarán el flujo dilatante, lo que dificultará las operaciones mencionadas. En la Tabla 2 se muestran los puntos de fluidez determinados en distintas condiciones de ajuste, seleccionando distintos tramos de velocidad y distintos modelos. Asimismo, se muestran los valores determinados por otras técnicas reométricas, que se irán explicando a lo largo del trabajo. En este caso, cuando se ajusta la curva completa (curva 3), la mejor regresión se obtiene con los modelos de Bingham y Casson, pero en este último caso se obtiene un punto de fluidez alto, pero negativo. Es decir, la suspensión es dilatante. Como se aprecia en la tabla, si el ajuste se realiza en el tramo de 0-200 $\mathrm{s}^{-1}$ (curva 2) se obtienen puntos de fluidez muy bajos, indicando un comportamiento pseudoplástico. El ajuste de la región de alta velocidad (200-600 s-1) da un comportamiento plástico según el modelo de Casson (con un punto de fluidez de 3,85 $\mathrm{Pa}$ ), pero en el ajuste de Bingham se obtiene un punto de fluidez de casi $-28 \mathrm{~Pa}$, mucho más dilatante que si se considera la curva completa. El punto de fluidez negativo observado en los ajustes de Casson indica
TABla 2. Puntos de FluideZ APARENTE, DETERMINADOS PARA DIFERENTES AJUSTES Y RANGOS DE MEDICIÓN

TABle 2. Apparent Yield Stress, Determined For DifFERENT FITting MODELS AND MEASUREMENTS RANGES

\begin{tabular}{|c|c|c|c|c|}
\hline $\begin{array}{c}\text { Measurement } \\
\text { mode }\end{array}$ & Experimental Range & Fitting model & $\begin{array}{c}\text { Yield Stress } \\
{[\mathrm{Pa}]}\end{array}$ & Figure \\
\hline \multirow{6}{*}{ CR } & $0-600 s^{-1}$ & \multirow{3}{*}{ Bingham } & -12.39 & \multirow{6}{*}{ la } \\
\hline & $0-200 s^{-1}$ & & -0.517 & \\
\hline & $200-600 s^{-1}$ & & -27.98 & \\
\hline & $0-600 s^{-1}$ & \multirow{3}{*}{ Casson } & 0.472 & \\
\hline & $0-200 s^{-1}$ & & 0.152 & \\
\hline & $200-600 \mathrm{~s}^{-1}$ & & 3.830 & \\
\hline \multirow{4}{*}{ CS } & \multirow{2}{*}{$0-35 s^{-1}$} & Bingham & 7.68 & \multirow{2}{*}{2} \\
\hline & & Casson & 3.810 & \\
\hline & $0.04-2 \mathrm{~Pa}$ & \multirow{2}{*}{$\log (\gamma)$ vs $\log (\tau)$} & 0.376 & \multirow{2}{*}{3} \\
\hline & $2-20 \mathrm{~Pa}$ & & 2.438 & \\
\hline \multirow[b]{2}{*}{$\mathrm{CS}+\mathrm{CR}$} & $0.01-320 \mathrm{~Pa}$ & $\log (\eta)$ vs $\log (\tau)$ & $0.485-1.158$ & 4 \\
\hline & $0.001-1000 \mathrm{~s}^{-1}$ & $\log (\tau)$ vs $\log (\dot{\gamma})$ & $\begin{array}{ll}\text { (2) } & 7.68 \\
\text { (3) } & 4.80\end{array}$ & 5 \\
\hline Oscillation & $0-10 \mathrm{~Pa}$ & $\left(G^{\prime}, \delta\right)$ vs $\tau$ & 0.379 & 8 \\
\hline
\end{tabular}

different kinds of interactions. The change in the measuring conditions (stresses or rates) promote a change in the arrangement of particles and in the interactions among them and thus in the rheological behaviour. Many ceramic suspensions show irregular flow curves with different parts each one corresponding to a different behaviour. This makes necessary a criterium for the fitting in order to avoid important errors. This is illustrated in Figure 1.a that shows the flow curve for the suspension described in the experimental part measured in CR mode. This is the usual measurement method where the opposition of the slip to flow (stress) for an increasing velocity gradient is measured. In this plot a normal scale from 0 to $600 \mathrm{~s}^{-1}$ is shown. The slip shows a complex behaviour combining a Bingham plastic flow at low rates $\left(0-200 \mathrm{~s}^{-1}\right)$ and an apparent dilatancy in the high shear region (200-600 s-1). This change should be considered in the subsequent processing operations since an energetical mixing or milling, pumping or high pressure injection will promote the dilatant behaviour difficulting those operations. Table 2 shows the yield values determined in different fitting conditions by selecting different steps in the flow curve and different regression models. In addition, it shows also the values determined by other rheometric techniques that will be explained along this work. When the whole curve is considered (curve 3) the best fitting is obtained with Bingham and Casson models, but in the last a high negative yield value is obtained which has no sense. The behaviour could be associated to a dilatant flow. When considering the first part of the curve, between $0-200 \mathrm{~s}^{-1}$ (curve 2) very low yield values are obtained, indicating a pseudoplastic flow. In the high shear region (200-600 s $\mathrm{s}^{-1}$ ) the fitting with the Casson model gives a yield value of $3.85 \mathrm{~Pa}$, whereas the Bingham model gives a value of $-28 \mathrm{~Pa}$, much more negative than when considering the whole curve. The observed negative yield value indicates a dilatant behaviour. That is, each seg- 
un comportamiento dilatante. Es decir, cada segmento tiene un comportamiento distinto, por lo que para controlar el flujo de la suspensión se debe estimar previamente el rango de velocidades al que va a estar sometida la suspensión.

Si se amplía la escala para observar con mayor nitidez la región de baja velocidad, vemos que el número de puntos medidos en esta zona es insuficiente para una determinación exacta del punto de corte con el eje de ordenadas (Figura 1b). A valores de gradiente cercanos a cero no se sabe con exactitud el valor concreto del par gradiente/esfuerzo. El ajuste de Bingham en el tramo 0-35 $\mathrm{s}^{-1}$ revela un punto de fluidez de unos $2 \mathrm{~Pa}$, muy similar al obtenido con el ajuste de Casson. En esta escala, los valores del ajuste de Bingham prácticamente coinciden con los puntos experimentales de la curva, mientras que en las escalas anteriores la enorme desviación conducía a valores absurdos.

Un parámetro muy útil en la evaluación de las curvas de flujo es el índice de flujo, n, del modelo de Ostwald-De-Waele, el cual evitaría operar con valores negativos del esfuerzo umbral. Un valor de $\mathrm{n}>1$ indica dilatancia. Sin embargo, dicho modelo no suministra información sobre el punto de fluidez.

Los datos suministrados por un viscosímetro rotacional a velocidad controlada pueden ser suficientes para establecer el comportamiento general en distintas condiciones de cizalla, pero son claramente restringidos en la región de baja velocidad, la cual puede ser determinante en la evaluación del comportamiento de la suspensión en reposo, sea en un tanque, sea en el interior de la cavidad de un molde de escayola durante el colaje. En consecuencia, la determinación del punto de fluidez exige un sistema de medida más preciso.

\section{OPERACIÓN A ESFUERZO CONTROLADO}

El punto de fluidez define el límite de esfuerzo por debajo del cual la suspensión no fluye, comportándose como si fuera un sólido elástico (9-12). En esta región, al aplicar un esfuerzo $\tau$, la muestra se deforma elásticamente como un sólido de Hook, $\tau=\mathrm{G} \gamma$ ec. 1

donde $G$ es el módulo de cizalla y $\gamma$ es la deformación. Cuando ésta cae a cero, la muestra recupera su forma original (lo que se representa mediante un muelle), pero cuando el esfuerzo aplicado es grande, puede destruir la estructura de la muestra. En tal caso, la muestra no solo se deforma, sino que además comienza a fluir, lo que define un comportamiento viscoso que corresponde, en el caso más simple, a la ley de Newton

$$
\tau=\eta_{\dot{\gamma}}
$$

ec. 2

La medida efectuada controlando el esfuerzo es mucho más precisa en la zona de baja velocidad. Al aplicar un esfuerzo, el aparato registra la evolución de la deformación que sufre la muestra hasta que empieza a fluir, con lo que mide una mayor cantidad de puntos antes del flujo. Además de la medida en velocidad controlada (figura 1), en la que se mide el esfuerzo resultante al aplicar un gradiente de velocidad, se ha procedido a la medida de la curva de flujo de una porción diferente de la misma suspensión en modo CS, en el cual se introduce un esfuerzo y se mide el gradiente de velocidad. Los resultados se muestran en la figura 2. Se aprecia mucho más claramente el hábito de la curva, que no se corresponde con el ajuste de Bingham ni con los datos obtenidos en modo CR. Junto a la curva experimental, que muestra un comportamiento pseudoplástico, se muestran los ajustes de Bingham y Casson, que dan puntos de fluidez de 7,7 y 3,8 Pa, respectivamente (Tabla ment has a different kind of behaviour so that the control of the flow requires a previous estimation of the rate range operating on the slip in the different processing steps.

Observation of the low rate region proves that the number of measured points is too limited to accurately determine the interception with the y axis (figure 1.b). For near to zero gradients the pair shear stress/shear rate cannot be accurately measured. Bingham regression in the segment $0-35 \mathrm{~s}^{-1}$ reveals a yield value of about $2 \mathrm{~Pa}$, very similar to that obtained with Casson model. The points of the Bingham model are practically coincident with those experimentally obtained in that range, whereas in the scales discussed above the broad deviation led to senseless values.

A useful parameter in the evaluation of flow curves is the flow index, n, of the Ostwald-De-Waele model, which allows a very good slip behaviour fitting. If this parameter is $n>1$ the slip is dilatant. However, this model does not provide any information about the yield point.

The data provided by a rotational viscosimeter under control rate can be sufficient to establish the general behaviour under different shearing conditions but are clearly restricted in the low rate region that can be determining for a proper evaluation of the slip behaviour at rest, either in a tank or into the mould cavity during slip casting. Consequently, the determination of the yield value requires more precise measurement methods.

\section{OPERATION AT CONTROL STRESS MODE}

The yield value defines a stress below which the suspension does not flow behaving like an elastic solid (9-12). In this region the sample elastically deformates like a Hookean solid when applying a stress $\tau$,

$$
\tau=\mathrm{G} \gamma
$$

where $G$ is the shear modulus and $\gamma$ the strain. When this falls to zero the sample recovers the original shape (what is represented by a spring), but when the applied stress is large the sample structure can break down. In this case the sample not only deformates but starts to flow. This defines a viscous response that in the simplest case corresponds to the Newton`s law:

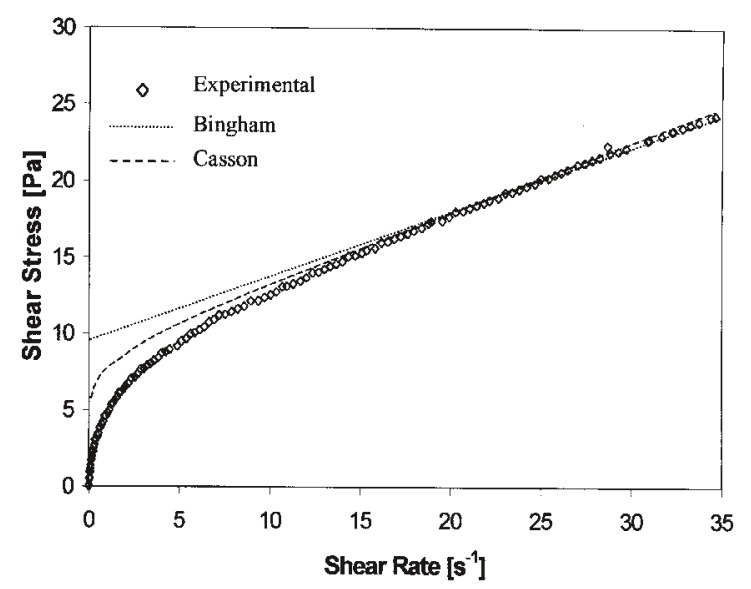

Figura 2. Curva de flujo determinada en modo CS, ajuste de Bingham y Casson, en el rango 0 a $35 \mathrm{~s}^{-1}$.

Figure 2 Flow curve measured in CS mode for Bingham and Casson fittings in the range 0 a $35 \mathrm{~s}^{-1}$. 
2), los cuales tampoco coinciden entre sí ni con los puntos experimentales.

Por tanto, a valores de velocidad cercanos a cero no es fácil determinar el punto de fluidez y, por lo tanto, se hace muy dificil valorar si la suspensión es plástica o pseudoplástica. En estos casos se hace necesario el uso del reómetro de esfuerzo controlado. Haciendo uso de estos equipos más sofisticados se puede calcular con mayor precisión el punto de fluidez a partir de la representación de la deformación de la muestra en función del esfuerzo aplicado en un diagrama doblemente logarítmico (9). Para el caso de la suspensión al $50 \%$ vol considerada, el diagrama obtenido al representar de esta forma los datos recogidos en la figura 2, se muestra en la Figura 3. La curva resultante se puede ajustar con dos rectas de distinta pendiente. En un primer ajuste obtendríamos las rectas 1 y 3 . El cambio de pendiente supone un cambio de la región de deformación elástica a la de un flujo viscoso, que se puede asociar al punto de fluidez. En este caso, se obtiene un valor inferior al obtenido en los ajustes anteriores. Sin embargo, los puntos de la región II no ajustan a ninguna de las dos rectas. Dichos puntos constituyen una zona de transición, que se podría ajustar con una nueva recta. Con este análisis se pone de manifiesto la existencia de dos puntos de corte, a valores de esfuerzo de 0,38 y 2,44 Pa (también mostrados en la Tabla 2). Es decir, en realidad el punto de fluidez no es un valor exacto, sino que hay toda una zona de cambio de comportamiento elástico a viscoso, por lo que habría que hablar de una "región de transición elástico/viscosa" en la que se produce gradualmente el cambio de comportamiento. En esta representación se obtiene un valor orientativo del esfuerzo crítico para el final de la región viscoelástica lineal. A la hora de considerar un punto de fluidez único, lo mejor es tomar como tal el valor mínimo, ya que a partir de él se empiezan a producir cambios. En la suspensión aquí estudiada el valor de fluidez obtenido con esta representación doblemente logarítmica es muy bajo $(0,38 \mathrm{~Pa})$, por lo que la suspensión puede considerarse pseudoplástica.

En el conformado cerámico es útil que la suspensión fluya bien a cierto gradiente de velocidad, pero a bajas velocidades interesa que la viscosidad aumente, con el fin de retardar posibles fenómenos de sedimentación. Sin embargo, la plasticidad

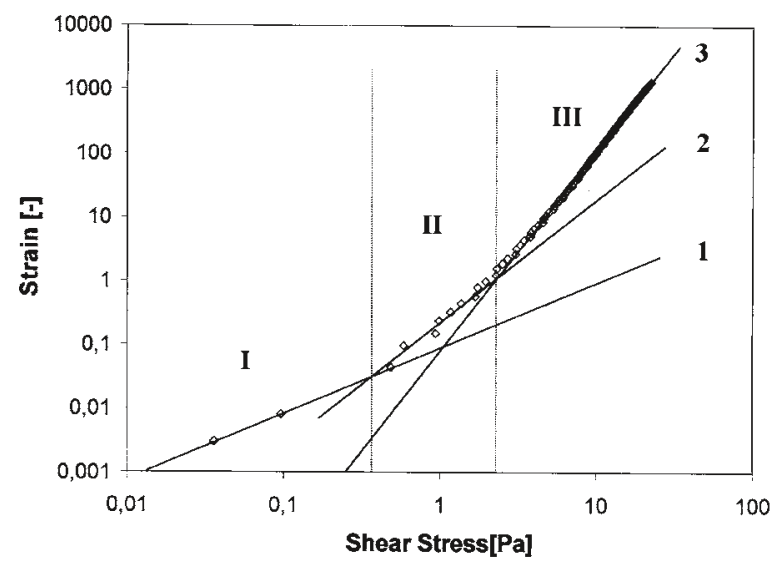

Figura 3. Representación logarítmica de la curva de flujo en modo CS en función de deformación y esfuerzo. Ajuste en rangos de 0.04 a 2Pa y 2 a $20 \mathrm{~Pa}$.

Figure 3. Logarithmic plot of a CS flow curve of strain vs. stress. Fitting in the 0.04-2Pa and 2-20Pa ranges.

$$
\tau=\eta \gamma
$$

The control stress measurement is much more precise in the low rate region. When a stress is applied, the evolution of the sample strain before it flows is registered and a larger number of points is measured. In adition to the control rate measurement (figure 1), in which the stress resulting after applying a velocity gradient, the flow curve of the considered slip has been also determined in CS mode, where a stress is applied and the resulting velocity gradient is measured. The results are shown in Figure 2. The shape of the curve is better observed and does correspond neither to the Bingham fit nor to the experimental CR data. With the experimental curve exhibiting a pseudoplastic behaviour, the Bingham and Casson regressions are also shown. These models provide yield values of 7.7 and $3.8 \mathrm{~Pa}$, respectively (Table 2) that deviate also from experimental data.

Hence for near-to-zero shear rates the yield value determination is complex and therefore it is difficult to estimate if the suspension behaves as plastic or as pseudoplastic. In such cases the control stress rheometer is necessary. Making use of these sophisticated equipments it is possible to accurately determine the yield value by plotting the strain of the sample as a function of the applied stress in a double logarithmic diagram (9). For the considered suspension with 50 vol\% solids the diagram obtained considering the data reported in figure 2 is plotted in Figure 3. The resulting curve can be adjusted by two straight lines with different slope. In a first fitting the lines 1 and 3 would be obtained. The slope change means a change from the region of elastic deformation to a viscous flow which can be associated with the yield value. In our case, the value is lower than those obtained according to the previous procedures. However, the points in region II do not fit to any of both lines, but are in a transition region that could be adjusted with a third line. With this analysis two different intercepting points can be distinguished at shear stresses of 0,38 y 2,44 $\mathrm{Pa}$ (also shown in Table 2). That is, there is not a true yield value as an exact value but all a region where behaviour slowly changes from elastic to viscous, so it should be necessary to refer it as a "fluidity region" with a gradual change. In this plot an esti-

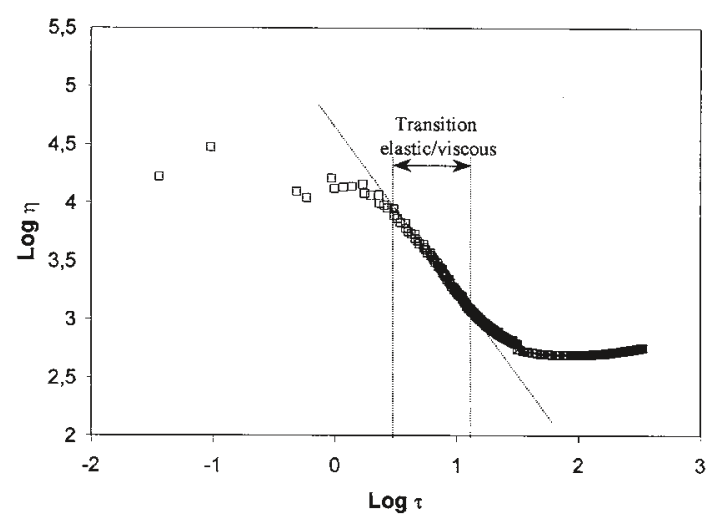

Figura 4. Representación logarítmica de viscosidad y esfuerzo tras combinar las medidas en modo CS y CR.

Figure 4. Logarithmic plot of viscosity and stress by combining CS+CR flow curves. 
puede suponer dificultades de reproducibilidad en la obtención y menor uniformidad ( $\mathrm{y}$, en consecuencia, menor densidad) en la pieza consolidada, ya que la existencia de un punto de fluidez supone la formación de estructura que en la región de baja velocidad, no llega a romperse. La observación grosera de la curva de flujo CR, y el mejor ajuste (Bingham) indicaban que la suspensión era plástica, pero un ajuste adecuado demuestra que el comportamiento es pseudoplástico, como era de desear.

Este método es muy preciso para evaluar si la suspensión es plástica o pseudoplástica a través del punto de fluidez. Como ya se ha comentado antes, no es del todo exacto hablar del punto de fluidez como aquel en el que cambia la estructura elástica a viscosa sino en toda una región de transición, donde la unión de las dos regiones rectilíneas precisa una curva que las una. Para ilustrar este concepto, la figura 4 muestra una forma distinta de representar la curva de flujo CR (con los datos de la figura 1) en la que se relaciona el logaritmo de la viscosidad con el logaritmo del esfuerzo (13). En la curva resultante se aprecia una zona intermedia en la que hay una reducción en la viscosidad, correspondiente a la zona de transición de la respuesta de fluidez. Aunque en la práctica es más sencillo considerar un punto de fluidez específico, esta representación demuestra que es mejor considerarlo como un rango de esfuerzos en los que la viscosidad cambia bruscamente. La curva resultante corresponde a un fluido pseudoplástico, en el que se puede apreciar una primera región newtoniana con una viscosidad límite, que indica que no hay punto de fluidez.. En uno plástico, la viscosidad seguiría creciendo al disminuir el esfuerzo (paralelamente al eje y) y no tendería a alcanzar un valor constante de $\log \eta$. Este sería un método muy sencillo de evaluar la plasticidad de la suspensión. En esta gráfica se obtiene una zona de inflexión entre 0,2-1 Pa, valores más bajos que los obtenidos en la representación típica de la curva de flujo $(\tau / \gamma)$. Si se compara esta curva con la mostrada en la figura 3; se puede comprobar la existencia de la región II de aquella, correspondiente a la transición elástico/viscosa.

Por otra parte, además de una mejor estimación del punto de fluidez, la combinación de los modos de operación CR y CS permite representar los datos de esfuerzo/velocidad en un rango de valores muy superior al obtenido solo en $\mathrm{CR}$, lo que proporciona, de forma muy sencilla, una gran cantidad de información. Así, para la suspensión de porcelana sanitaria seleccionada, la figura 5 muestra, en escala doblemente logarítmica, la curva de flujo expandida, considerando los datos obtenidos en el rango normal de la medida CR, con los obtenidos en la región de baja velocidad mediante medidas CS. Esta curva proporciona varios datos de interés $(10,13)$. Para empezar, se tiene información del comportamiento reológico en un rango de gradientes de velocidad de $10^{-3}$ a $10^{3}$, es decir, 6 órdenes de magnitud. Cada mative value of the critical yield for the begining of the linear viscoelastic region is obtained. When it is needed to consider a concret value it is better to take the minimum as changes start to occur from that minimum. In the studied suspension the yield value obtained from the double logarithmic diagram is very low $(0,38 \mathrm{~Pa})$, so it can be considered as pseudoplastic.

In ceramic forming it is useful that slip flows well at a certain shear rate but at very low rates the viscosity should be high in order to avoid sedimentation phenomena to occur. On the other hand, plasticity could lead to problems regarding reliability of the process or uniformity of the shaped part (i.e. lower density) as the existance of a yield means that a structure is formed that cannot break down in the low rate region. Direct observation of the flow curve in CR mode and best fitting (Bingham) indicated that the studied slip was plastic, but a proper analysis shows that it behaves as pseudoplastic, as usually desired.

This method is useful to evaluate plasticity or pseudoplasticity through yield value. As mentioned before it is not exact to consider a yield point where elastic to viscous transition occurs but it is preferable to consider a transition region as that linking the two linear zones. To illustrate this figure 4 shows a different representation of the CR flow curve (with the same data as in figure 1) where the logarithm of viscosity is related to logarithm of stress (13). In that curve an intermediate region is appreciated corresponding to the transition to the flow response. Although it is easier in practice to consider a punctual yield this plot demonstrates that it consists on a region in which viscosity changes. The resulting curve corresponds to a pseudoplastic fluid and the presence of a initial Newtonian region with a limit viscosity is observed indicating that there is not yield point. In a plastic one viscosity should increase more and more for decreasing stresses (parallel to y axis) and should not tend to a constant value of $\log \eta$. This is an easy way to evaluate plasticity of a slip. In the experimental plot an inflexion zone between 0.2 and $1 \mathrm{~Pa}$ is obtained, these values being lower than those obtained in the typical flow curve $(\tau / \gamma)$. When comparing with figure 3 , the presence of region II corresponding to elastic/viscous transition is confirmed.

In addition to a better estimation of the yield the combination of $\mathrm{CR}$ and $\mathrm{CS}$ modes allows to plot the stress/rate data in a broader range than in the $\mathrm{CR}$ mode thus giving an easy procedure to get much more information. For the porcelain slip selected figure 5 shows a double logarithmic diagram of the expanded flow curve obtained combining the data measured in the normal $\mathrm{CR}$ range and those obtained in the low shear region by CS mode measurements. In this plot different interesting data are given $(10,13)$. First, there is information about the rheological behaviour in a broad 
uno de los tramos de las regiones de baja y alta velocidad pueden ajustarse con una recta con una pendiente de $45^{\circ}$. Extrapolando cada una de ellas hasta cortar a la recta $\log \gamma=0$ se obtienen los valores de viscosidad a cizalla cero (punto 1) y la viscosidad límite a alta cizalla (punto 4). Entre ambos tramos rectilíneos, hay una región de transición, en el que se produce la inflexión de la curva. La prolongación curvilínea del tramo de alta velocidad hasta el eje de ordenadas (punto 2) correspondería al límite de Bingham, mientras que el observado directamente en la curva de flujo sería el punto 3.

\section{VISCOELASTICIDAD}

\subsection{Ensayos de fluencia.}

Como ya se ha comentado, el punto de fluidez separa dos regiones de comportamiento, que se pueden asociar a la respuesta de un sólido ideal y de un líquido ideal a un esfuerzo aplicado. En un sólido ideal, al aplicar un esfuerzo dado la muestra sufre una deformación instantánea proporcional a aquel, mientras que un líquido se deforma a velocidad constante. Al interrumpir la tensión el sólido recupera su forma instantáneamente, mientras que el líquido permanece deformado. Sin embargo, muchas de las suspensiones empleadas en cerámica exhiben propiedades viscosas y elásticas, comportándose como fluidos visco-elásticos. La forma más sencilla de determinar la respuesta viscoelástica de una suspensión es mediante ensayos de fluencia (creep/recovery), en los cuales se considera como parámetro adicional el tiempo de respuesta a la dependencia del comportamiento elástico o viscoso con el esfuerzo aplicado (9)

Este tipo de ensayos se lleva a cabo en dos etapas: en la primera, la muestra se somete a un esfuerzo instantáneo, que se mantiene durante un cierto tiempo, y se mide la deformación experimentada por la suspensión mientras está sometida a dicho esfuerzo. En la segunda etapa se libera el esfuerzo y se determina el comportamiento de recuperación con el tiempo.

La figura 6.a muestra el comportamiento de un sólido ideal en un ensayo de fluencia. La muestra sufre una deformación constante mientras se aplica el esfuerzo y recupera instantáneamente, por lo que puede representarse por un muelle. En el líquido ideal no hay recuperación, y su respuesta es de la forma que se muestra en la figura 6.b. Esta situación se representa mediante un amortiguador. Los fluidos viscoeláticos presentan un comportamiento complejo con contribuciones elásticas y viscosas, que se pueden representar mediante la disposición en serie o en paralelo de muelles y amortiguadores. Cuando se aplica un esfuerzo puede ocurrir deformación instantánea o ésta puede requerir un cierto tiempo. En la figura 6.c se muestra la respuesta más general de un fluido viscoelástico, en la que la pendiente va disminuyendo durante el tiempo de aplicación del esfuerzo y puede alcanzar un valor constante dependiendo del tiempo. Entonces se comportaría como un fluido viscoso puro. En la etapa de recuperación la dependencia con el tiempo es muy grande, por lo que una medida exacta de ambas contribuciones podría llegar a requerir tiempos de relajación muy prolongados. El tipo de respuesta representado en la figura 6.c responde al modelo de Burger, resultante de la combinación de dos pares muelle/amortiguador, uno en serie y otro en paralelo.

En suspensiones de partículas se puede formar una red tridimensional, la cual aumenta la rigidez provocando una respuesta elástica (sólido) a bajos valores de esfuerzo. A valores

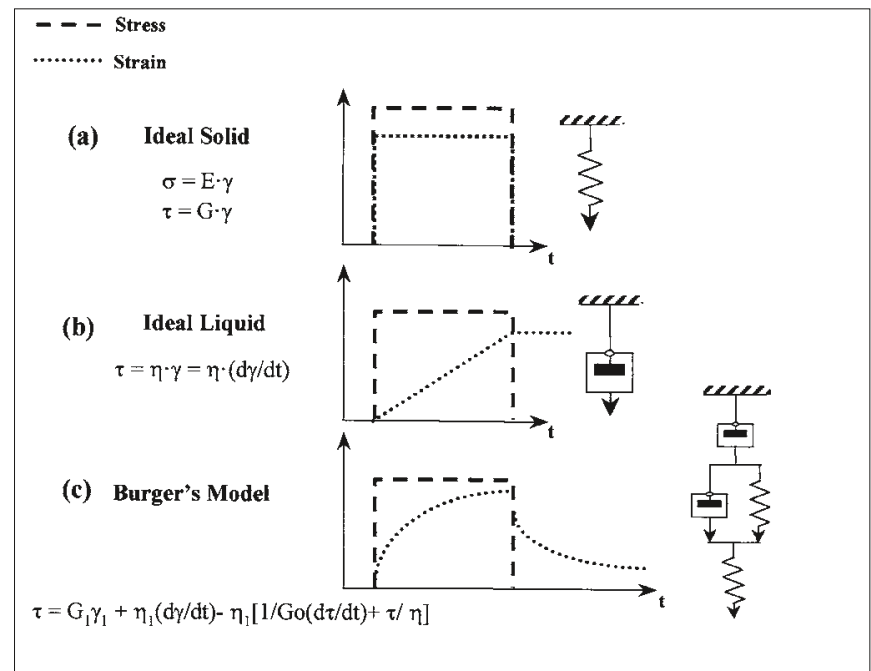

Figura 6. Representación esquemática de los modelos de fluencia.

Figure 6. Schematic representation of common creep-recovery models.

shear rate region $10^{-3}$ a $10^{3}$, that is, 6 orders of magnitude. Each shear rate region can be fit with a straight line with a slope of $45^{\circ} \mathrm{C}$. Extrapolating to interception with the line $\log \dot{\gamma}=0$ the zero shear viscosity (point 1 ) is obtained, as well as the limit viscosity at high shear (point 4). Between both linear regions there is a transition zone. The extrapolation of the line at the high shear region towards the y axis (point 2) corresponds to the Bingham yield point, whereas the yield value directly observed in the normal flow curve corresponds to point 3 .

\section{VISCOELASTICITY}

\subsection{Creep-recovery tests.}

As mentioned before the yield value separates two regions of behaviour that can be asociated to the response of an ideal solid and an ideal liquid to any applied stress. When a stress operates onto a solid it instantaneously deformates in proportion to the stress whereas a liquid deformates at constant rate. When the stress stops the solid recovers instantaneously the original shape but the liquid remains deformated. However, many ceramic suspensions exhibit both elastic and viscous properties and behave as viscoelastic. The simplest way to determine the viscoelastic response of a slip is by means of creep-recovery tests, where the response time to the dependence of elastic or viscous behaviour with the applied stress is considered an additional parameter (9).

These tests are performed in two steps: in the first the sample is forced to an instantaneous stress which is maintained a certain time and the resulting deformation is measured. In a second step the stress is interrupted and the recovering of the slip with time is then measured.

Figure 6.a shows the behaviour of an ideal solid in a creeprecovery test. The sample experiments a constant deformation during the stress application and this is usually represented by a spring. In the ideal liquid there is not recovering after the stress application and the response can be represented as shown in figure 6.b. This can be represented by a dashpot. Viscoelastic fluids are complex in nature as they have both elastic and viscous contributions which can be 
suficientemente altos de esfuerzo se rompe dicha estructura, resultando en una respuesta viscosa (líquido). Dado que por encima del punto de fluidez la suspensión fluye libremente, la medida de la viscoelasticidad tiene que llevarse a cabo en la zona de baja tensión de cizalla (por debajo del punto de fluidez), en la que puede existir respuesta elástica del material.

En la suspensión estudiada, la respuesta a ensayos de fluencia se muestra en la figura 7 , en la que se muestra la respuesta de la muestra frente a la aplicación de dos valores de esfuerzo. El hábito de la curva es el mismo en ambos casos, con una deformación instantánea aunque incompleta, y una disminución de pendiente al aumentar el tiempo de aplicación del esfuerzo, hasta alcanzar una deformación constante (cuando se aplica un esfuerzo de 2Pa). Liberado el esfuerzo, la suspensión comienza su recuperación, si bien ésta no es completa. El hecho de que no se llegue a alcanzar un valor constante supone que el ensayo no ha sido completo, por lo que precisaría evaluar la respuesta a mayores tiempos de relajación.

\subsection{Ensayos dinámicos.}

Otra aproximación más compleja a la medida del comportamiento reológico de suspensiones es mediante ensayos dinámicos o de oscilación $(9,10)$. En ellos, en vez de aplicar un gradiente de velocidad o un esfuerzo, lo que se hace es aplicar una deformación o esfuerzo oscilatorio. Los ensayos dinámicos permiten caracterizar la viscosidad y la elasticidad en función del tiempo de respuesta, relacionando la velocidad angular o frecuencia con el esfuerzo o deformación de oscilación. Por tanto, son la herramienta más completa para la caracterización de la viscoelasticidad de suspensiones.

La respuesta elástica (muelle) a un esfuerzo aplicado viene dada por la ecuación 1, mientras que la respuesta viscosa (amortiguador) corresponde a la ley de Newton (ec. 2). Al aplicar una deformación sinusoidal $(\gamma)$, la ecuación que describe la respuesta elástica es:

$$
\gamma=\gamma_{0} \text { sen }(\varpi \mathrm{t})
$$

donde $\gamma_{0}$ es la deformación máxima, $\varpi$ la velocidad angular $(\varpi=2 \pi \mathrm{f})$ y $\mathrm{t}$ el tiempo. Esta ecuación define la función de esfuerzo que, para un sólido ideal, sería de la forma:

$$
\tau=\mathrm{G} \gamma_{0} \operatorname{sen}(\varpi \mathrm{t})
$$

Según estas ecuaciones, la deformación y el esfuerzo están

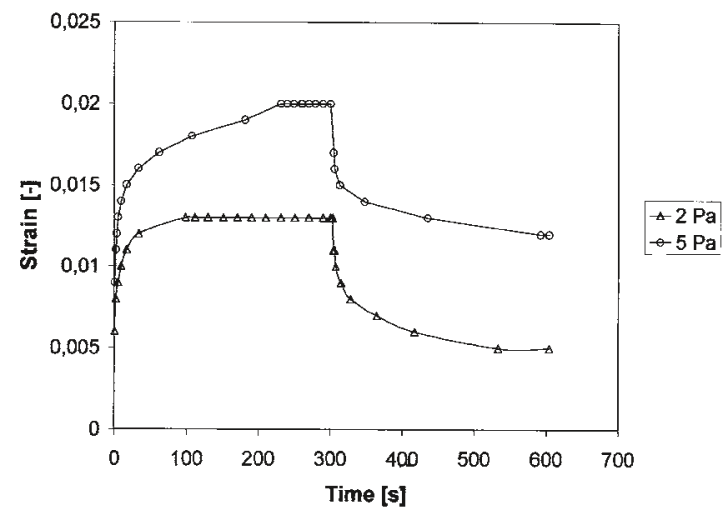

Fig. 7. Resultados de los ensayos de fluencia.

Fig. 7. Results of creep-recovery tests. represented as combination in series or in parallel of springs and dashpots. When a stress is applied the deformation can be instantaneous or can start after a certain time. Figure 6.c shows a more general response of a viscoelastic fluid in which the slope decreases as the time of application of the stress increases and can reach a constant value depending on the time scale. Then it should be considered a pure viscous fluid. In the recovering step the time dependency is large so an accurate measurement of both contributions can take very prolongated relaxation times. The response plotted in figure 6.c corresponds to the Burger model which results from the combination of two pairs spring/dashpot, one in series and the other one in parallel.

In particulate systems a tridimensional network can be formed then increasing the rigidity that promotes an elastic response (solid like) at low shear stresses. For sufficiently high shear stresses that network breaks down promoting a viscous response (liquid). Since above the yield value the suspension is free to flow the viscoelastic measurements should be performed in the low shear stress region (below the yield value) where the elastic response dominates.

In the studied suspension the response to creep-recovery tests is shown in figure 7 , where the response to two different applied stresses is plotted. The shape of the curve is the same in both cases, with an instantaneous but incomplete deformation and a decrease of the slope for increasing times of stress application until a constant deformation is reached (for a stress of $2 \mathrm{~Pa}$ ). When the stress ceases the slip starts to recover although recovering is not complete. The fact that a constant value has not been reached suggests that the test has not been complete but longer relaxation times should be required.

\subsection{Dynamic measurements.}

A more complex approach to suspension rheology is the use of oscillation or dynamic measurements $(9,10)$. In this case the application of a linear stress or rate is replaced by a sinusoidal stress or strain. Dynamic tests allow to characterize the viscosity and the elasticity as a function of response time, relating the angular velocity or frequency with the oscillatory stress or strain. Consequently, these tests constitute the most complete tool for the characterization of viscoelasticity in suspensions.

The elastic response (spring) to an applied stress is given by equation 1, whereas the viscous response (dashpot) corresponds to the Newton`s law (eq. 2). The equation describing an elastic response when a sinusoidal strain is applied is:

$$
\gamma=\gamma_{0} \operatorname{sen}(\varpi \mathrm{t})
$$

being $\gamma_{0}$ the maximum deformation, $\varpi$ the angular velocity $(\varpi=2 \pi \mathrm{f})$ and $\mathrm{t}$ is time. This equation defines the stress function that for an ideal solid is given by :

$$
\tau=\mathrm{G} \dot{\gamma}_{0} \text { sen }(\varpi \mathrm{t})
$$

eq. 4

According to these equations, strain and stress are "in phase". However, the response of an ideal fluid (viscous) is given by:

$$
\tau=\eta \gamma=\eta \omega \gamma_{0} \cos (\varpi \mathrm{t})
$$

where strain and stress are "out of phase" with an angle $\delta=90^{\circ}$, so this equation can be rewritten as:

$$
\tau=\eta \omega \gamma_{0} \text { sen }(\varpi \tau+\delta)
$$

A viscoelastic fluid will be then characterized by an intermediate angle between $0^{\circ}$ (elastic) and $90^{\circ}$ (viscous). In a 
en fase. Sin embargo, la respuesta de un fluido ideal (viscosa) viene dada por:

$$
\tau=\eta \gamma=\eta \omega \gamma_{0} \cos (\varpi \mathrm{t})
$$

en donde la deformación y el esfuerzo están desfasados en un ángulo $\delta=^{\circ} 90^{\circ}$, por lo que se puede reescribir la ecuación anterior de la forma:

$$
\tau=\eta \omega \gamma_{0} \operatorname{sen}(\varpi \tau+\delta)
$$$$
\text { ec. } 6
$$

Un fluido viscoelástico vendrá, pues, caracterizado por un ángulo de fase intermedio entre $0^{\circ}$ (elástico) y $90^{\circ}$ (viscoso). En una medida dinámica en modo CR la deformación va asignada a una amplitud $\gamma_{0}$ y una velocidad angular $\varpi$, de acuerdo con la ecuación 3 . El esfuerzo resultante $(\tau)$ se mide con la amplitud del esfuerzo $\left(\tau_{0}\right)$ y el ángulo de fase $(\delta)$ :

$$
\tau=\tau_{0} \text { sen }(\varpi \tau+\delta)
$$

En reología se suele utilizar el término "módulo complejo" $\left(G^{*}\right)$, que viene dado por:

$$
\mathrm{G}^{*}=\tau_{0} / \gamma_{0}
$$

que representa la resistencia total de una substancia al esfuerzo aplicado. Como $G^{*}$ y $\delta$ dependen de la frecuencia, es preciso realizar un barrido de frecuencias para determinar la región de viscoelasticidad lineal, en la cual la viscosidad y la elasticidad no cambian al aumentar la amplitud de esfuerzo. Esto hace que las medidas dinámicas requieran tiempos de ensayo prolongados, a veces de hasta varias horas, frente a los escasos minutos normalmente empleados para obtener una curva de flujo. Sin embargo, la información que proporcionan dichas medidas es muy superior y más preciso, ya que los tiempos prolongados hacen posible la evaluación de la suspensión sin cambios bruscos.

El procedimiento experimental para el cálculo de módulos complejos es a través de una primera etapa en la que se hace un barrido de esfuerzos. Una vez fijado el valor crítico del esfuerzo por debajo del cual se obtiene la región viscoelástica lineal, se lleva a cabo un barrido de frecuencias. Al representar el módulo complejo o el ángulo de fase (también llamado ángulo de pérdidas) frente al esfuerzo, se observa un punto en el que ambos cambian su pendiente. Este cambio de pendiente está asociado nuevamente a la transición de comportamiento elástico a viscoso, es decir, al punto de fluidez de la suspensión.

Como su nombre indica, el parámetro $G^{*}$ es un módulo complejo, el cual está formado por dos términos,

$$
\begin{aligned}
& G^{*}=G^{\prime}+i G^{\prime \prime}=\tau_{0} / \gamma_{0} \\
& \text { en donde, } \\
& G^{\prime}=G^{*} \cos \delta=\tau_{0} / \gamma_{0} \cos \delta \\
& G^{\prime \prime}=G^{*} \operatorname{sen} \delta=\tau_{0} / \gamma_{0} \operatorname{sen} \delta \\
& i=\sqrt{-1}
\end{aligned}
$$

G`es el módulo elástico o de almacenamiento, así llamado porque almacena temporalmente la energía proporcionada por el esfuerzo aplicado, para después liberarla en forma de recuperación elástica. El término $G^{\prime \prime}$ se denomina módulo viscoso o de pérdidas, en referencia al hecho de que la energía usada en iniciar el flujo se pierde irreversiblemente en forma de calor de cizalla. En un sólido ideal, $G^{\prime}=G^{*}$ y $G^{\prime \prime}=0$, mientras que en un líquido ideal $G^{\prime}=0$ y $G^{\prime \prime}=G^{*}$. Por lo tanto, al evaluar una determinación experimental en oscilación, deberá observarse que la curva de G" esté situada por encima de la G', situación que indica un comportamiento viscoso puro. En términos de estabilidad de una suspensión, cuando esto ocurre la suspensión es estable.

Como en el caso del módulo complejo, se puede definir una viscosidad compleja $\eta^{*}$,

$\eta^{*}=G^{*} / \omega=\left(\tau_{0} / \gamma_{0} \omega\right) \operatorname{sen} \delta$

que, como en el caso anterior, se puede separar en dos térmi- dynamic test in CR mode deformation is associated to an amplitude $\gamma_{0}$ and an angular velocity $\varpi$, according to equation 3. The resulting stress $(\tau)$ is measured with the stress amplitude $\left(\tau_{0}\right)$ and the phase angle $(\delta)$ :

$$
\tau=\tau_{0} \text { sen }(\varpi t+\delta)
$$

In rheology the term "complex modulus" $\left(G^{*}\right)$ is used and is given by:

$$
\mathrm{G}^{*}=\tau_{0} / \gamma_{0}
$$

That represents the total resistance of a substance to any applied stress. As $G^{*}$ and $\delta$ depend on frequency, it is necessary to perform a frequency sweep to determine the linear viscoelastc region in which viscosity and elasticity keep constant when increasing the stress amplitude. This makes that dynamic tests need long testing times, up to several hours, in contrast with the few minutes typically employed in the determination of the CR flow curves. However, the information provided by these measurements is much higher and precise because prolongated times allow the evaluation of the slip avoiding sharp changes.

The experimental procedure for calculating complex moduli is through a two-steps process. First, a stress sweep is done and when a critical stress delimiting the linear viscoelastic region is obtained, a frequency-sweep is then performed. When plotting the complex modulus or the phase angle (also referred to as loss angle) against stress, there is a point in which a change of slope occurs. This change in slope is associated to the elastic to viscous transition, that is, to the yield point.

The parameter $G^{*}$ is a complex modulus, formed by two terms,

$$
\begin{aligned}
& \mathrm{G}^{*}=\mathrm{G}^{\prime}+\mathrm{i} \mathrm{G}^{\prime \prime}=\tau_{0} / \gamma_{0} \\
& \text { where, } \\
& \mathrm{G}^{\prime}=\mathrm{G}^{*} \cos \delta=\tau_{0} / \gamma_{0} \cos \delta \\
& \mathrm{G}^{\prime \prime}=\mathrm{G}^{*} \operatorname{sen} \delta=\tau_{0} / \gamma_{0} \operatorname{sen} \delta \\
& \mathrm{i}=\sqrt{-}-
\end{aligned}
$$

$\mathrm{G}^{\prime}$ is the elastic or storage modulus, because it stores temporarity the energy provided by the applied stress and afterwards liberates it as elastic recovering. The term $G^{\prime \prime}$ is referred to as viscous or loss modulus, referring to the fact that the energy used to initiate the flow is irreversibly lost as shear heat. In an ideal solid, $G^{\prime}=G^{*}$ and $G^{\prime \prime}=0$, whereas in an ideal liquid $G^{\prime}=0$ and $G^{\prime \prime}=G^{*}$. Then, when evaluating a oscillation measurement it should be observed that the curve of $G^{\prime \prime}$ is above that corresponding to $G^{\prime}$, thus indicating a pure viscous behaviour. In terms of stability, when this occurs the slip is stable.

As in the case of complex modulus, a complex viscosity $\eta^{*}$ can be defined,

$$
\eta^{*}=G^{*} / \omega=\left(\tau_{0} / \gamma_{0} \omega\right) \operatorname{sen} \delta
$$

that can be also separated in two different contributions, the storage viscosity $\eta$ “ (elastic component) and dynamic viscosity $\eta{ }^{`}$ (viscous component).

For the considered suspension of $50 \mathrm{vol} \%$ the evolution of complex modulus and phase angle with the stress (at a frequency of $1 \mathrm{~Hz}$ ) is shown in figure 8 . The initial linear zone corresponds to the linear viscosity region and the point intercepting the slopes of the two linear regions is associated to the yield stress, which gives a value of $0.38 \mathrm{~Pa}$. It is also clear that there is not a defined point but a region of transition where curvature gradually changes. The value obtained by this method is very similar to that obtained by the plot $\log \tau / \log \gamma$. Both methods are very precise, although oscillation tests provide an important additional information allowing the detailed analysis of the strain/stress relations- 
nos, la viscosidad de almacenamiento $\eta^{\prime \prime}$ (componente elástico) y la viscosidad dinámica $\eta^{\prime}$ (componente viscoso).

Así, para la suspensión utilizada en este trabajo al $50 \%$ vol de sólidos, la evolución del módulo complejo y del ángulo de fase con el esfuerzo (a una frecuencia de $1 \mathrm{~Hz}$ ) se muestra en la figura 8. La zona rectilínea inicial corresponde a la región viscoelástica lineal, y el punto de intersección de las pendientes de ambos tramos corresponde al punto de fluidez, que da un valor de 0,38 Pa. También en este caso se aprecia que no hay un punto de corte exacto, sino una región de transición en la que cambia gradualmente la curvatura. El valor determinado por este método es muy similar al obtenido con la representación $\log \tau / \log \gamma$. Ambos métodos son muy precisos, si bien los ensayos dinámicos proporcionan una información adicional importante, dado que permiten un análisis detallado de las relaciones tensión/deformación en la región viscoelástica lineal. En la manipulación de suspensiones concentradas, la deformación generada por la aplicación de un pequeño esfuerzo lleva consigo una distorsión de la estructura o cambio de posición de unas partículas con respecto a las más próximas. Si las distancias entre partículas se alteran, la energía de interacción entre ellas también cambia, ya que depende de la distancia de separación. En consecuencia, los potenciales netos de interacción entre partículas están directamente relacionados con los parámetros reológicos, por lo que su determinación puede emplearse no solo cualitativamente para seleccionar las mejores condiciones de preparación de una suspensión, sino que también pueden llegar a correlacionarse cuantitativamente con las fuerzas de interacción para predecir la estabilidad coloidal.

\section{SUMARIO}

De todo lo anterior se desprende que la determinación del punto de fluidez (como la de otros parámetros reológicos) no es trivial, sino que requiere un análisis detallado si se quieren evitar errores de interpretación. El hecho de que una suspensión se considere plástica o pseudoplástica tiene importantes consecuencias en el procesamiento cerámico. La plasticidad (punto de fluidez alto) dificulta el llenado o inyección de moldes y acelera la velocidad de formación de pared, lo que se traduce en una disminución de la densidad en verde y de la uniformidad microestructural. En este trabajo se han analizado diversos métodos de determinación del punto de fluidez, encontrándose enormes variaciones para una misma suspensión dependiendo del método elegido, tal y como se recoge en la Tabla 2. El ajuste de las curvas de flujo puede crear más confusión que ayuda, si no se elige correctamente el tramo de velocidades para el ajuste. En la Tabla 2 se muestra que se pueden dar valores del punto de fluidez tan dispares como -28 Pa y 3,8 Pa para la misma suspensión. La medida de curvas de flujo en modo CS proporciona mayor fiabilidad, pero la medida más precisa se obtiene mediante la representación gráfica de esfuerzo/deformación en escala doblemente logarítmica. Con este método se obtiene un valor más bajo y, por tanto, más fiable. Por otra parte, dado que las partículas en suspensión interaccionan entre sí, las propiedades reológicas no son parámetros estáticos, sino que presentan una gran dependencia con el tiempo. Los ensayos dinámicos (o de oscilación) permiten estudiar el comportamiento de la suspensión frente a tiempos de respuesta muy elevados, por lo que la determinación en estas condiciones es la más precisa de cuantas se puedan llevar a cabo. Por otra parte, se ha visto la importancia de la determi- hips in the linear viscoelastic region. When manipulating concentrated slips the deformation created by a small stress leads to a structure distorsion or rearrangement of particles. If the interparticle distances change the interaction energy also changes because it depends on separation distance. Consequently, the interparticle potentials are directly related to rheological parameters so that their determination not only provides useful information to select suitable processing conditions, but can be quantitatively correlated with interaction forces to predict colloidal stability.

\section{SUMMARY}

From the above it can be deduced that yield point determination is not obvious but requires a detailed analysis to avoid missunderstanding errors. The fact that a slip can be considered as plastic or as pseudoplastic has important consequencies in ceramic processing. Plasticity (high yield point) difficults mould filling or injection and acceleartes wall thickness rate in slip casting, which results in lower green densities and microstrutural uniformity. In this work different methods for determining the yield point have been analysed and big differences have been found for a same slip depending on the measurement method or fitting criteria, as shown in Table 2. The regression of flow curves can introduce great confusion if the correct range of shear rate is not selected. Table 2 shows that very different values can be obtained at different condition, including negative values. Measurements in CS mode provide larger reliability but a more precise measurement is reached with the plot strain/ stress in logarithmic scale. This method provides a lower yield value. On the other hand, as particles in a suspension interact among them, the rheological properties are not static

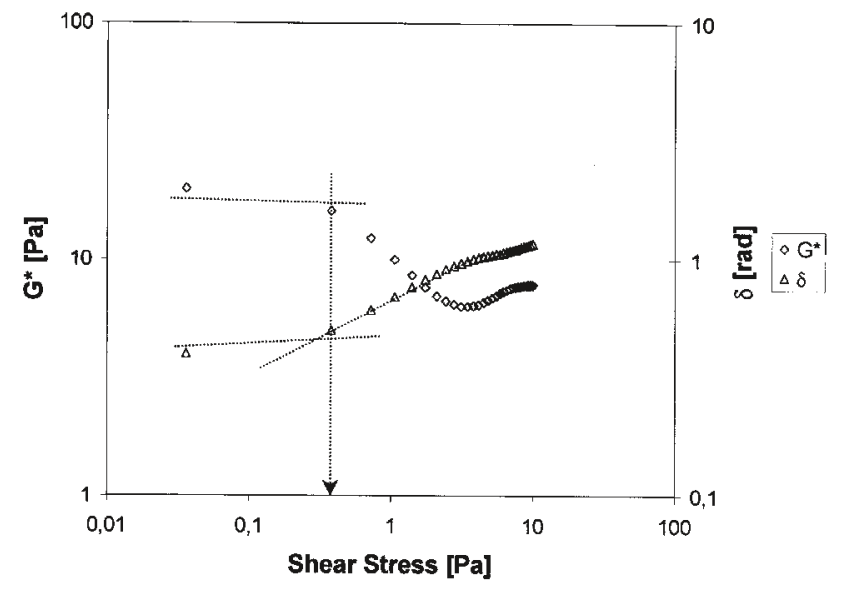

Figura 8. Ensayo de oscilación en modo de barrido de esfuerzo $(0$ a $10 \mathrm{~Pa})$ a $1 \mathrm{~Hz}$.

Figure 8. Oscillation tests in stress-sweep mode (0-10 Pa) at $1 \mathrm{~Hz}$. 
nación precisa del punto de fluidez. Sin embargo, la mayor precisión de las medidas permite distinguir con claridad la existencia de toda una región de transición de comportamiento elástico a viscoso, y no de un punto, aunque en la práctica conviene tener en cuenta el valor mínimo, ya que es a partir de ese punto donde se producen los cambios estructurales y las interacciones entre partículas.

\section{AGRADECIMIENTOS}

Este trabajo se ha realizado en el marco de un proyecto CICYT (MAT97-0676). C. Gutiérrez agradece al CONACyT (México) la concesión de una beca.

\section{BIBLIOGRAFÍA / REFERENCES}

1. "Reologia Ceramica Applicata", Società Ceramica Italiana, Faenza Editrice, Bologna (Italia) 1990.

2. E. Gippini, "Pastas Cerámicas", Sociedad Española de Cerámica y Vidrio, Madrid, 1979.

3. R. Moreno, J.S. Moya, J. Requena, “Colaje de Oxidos Cerámicos. II: Reología”, Bol. Soc. Esp. Ceram. Vidr., 25 [1] 3-9 (1996).

4. A. Albertazzi, E. Rastelli, "Evaluation of the Tixotropy and Yield Stress of Industrial Ceramic Slips Using a Torque-Type Viscometer", Cer. Acta 9 [4] 5-11 (1997).

5. J.S. Reed, Introduction to the Principles of Ceramic Processing", $2^{\text {nd }}$ ed., WileyInterscience, New York (EEUU) 1995.

6. D.W. Richerson. "Modern Ceramic Engineering. Properties, Processing and Use in Design" 2nd ed, Marcel Dekker, Inc., New York (EEUU) 1992.

7. D.M. Liu, "Control of Yield-Stress in Low-Pressure Ceramic Injection Moldings", Ceramics Int., 25, 587-92 (1999).

8. G. Schramm,"Introducción a la Viscosimetría Práctica", Haake, Karlsruhe (Alemania) 1984.

9. G. Schramm, "A Practical Approach to Rheology and Rheometry", Haake, Karlsruhe (Alemania), 1994.

10. H.A. Barnes, J.F. Hutton, K. Walters, "An Introduction to Rheology", en Rheology Series, 3. Elsevier, London (UK) 1989. parameters but are very time dependent. Dynamic or oscillation tests allow to study the behaviour of a slip to prolongated response times thus providing a great deal of precision. The practical importance of determining the yield point has been discussed. However, the most precise measurements allow to distinguish all a transition elastic to viscous range rather than a punctual yield. In practice it is convenient to consider the lowest value, where structural changes and rearrangement of particles start to occur.

\section{ACKNOWLEDGEMENTS}

This work has been supported by CICYT within the project MAT97-0676. C. Gutiérrez acknowledges to CONACyT (Mexico) for the concession of a grant.

11. C.W. Macosko, "Rheology. Principles, Measurements and Applications", VCH Publ., New York (EEUU) 1994.

12. L. Bergström, "Rheology of Concentrated Suspensions", pp. 193-244 en "Surface and Colloid Chemistry in Advanced Ceramic Processing". Eds. R.J. Pugh, L. Bergström. Marcel Dekker, Inc, New York (EEUU) 1994.

13. J.W. Goodwin, "Rheology of Ceramic Materials", Am. Ceram. Soc. Bull., 69 [10] 1694-98 (1990).

14. R. Buscall, J.W. Goodwin, M.W. Hawkins, R.H. Ottewill, "Viscoelastic Properties of Concentrated Lattices", J. Chem. Soc. Faraday Trans., 78, 2889-99 (1982).

15. L. Bergström, "Rheological Properties of $\mathrm{Al}_{2} \mathrm{O}_{3}-\mathrm{SiC}$ Whisker Suspensions", J. Mater. Sci., 31, 5257-70 (1996).

16. M.A Camerucci, A.L. Cavalieri, R. Moreno, "Slip Casting of Cordierite and Cordierite-Mullite Materials", J. Eur. Ceram. Soc., 18, 2149-57 (1998).

17. W.M. Carty, "The Colloidal Nature of Kaolinite", Am. Ceram. Soc. Bull., 77 [8] 72-76 (1999).

* Dirección Permanente: CINVESTAV, Unidad Saltillo, 25000 Saltillo, México 